\title{
On the amino acids in the urine of dairy cows fed urea as the sole or partial source of nitrogen
}

\author{
Matti Kreula and Terttu Ettala \\ Biochemical Research Institute, Kalevankatu 56 b, 00180 Helsinki 18, Finland
}

\begin{abstract}
The urinary amino acids in free and bound form were determined quantitatively in dairy cows fed urea and ammonium nitrogen as the sole (0-cows) or partial (ULP-cows) source of nitrogen. For comparison, amino acid determinations were performed also on the urine of cows on ordinary silage-cereals feed and pasture feed (NorPcows). The total amount ( $\mathrm{mg} / \mathrm{l}$ urine) of the free amino acids was the smallest with 0 -cows and the highest with NorP-cows on pasture feeding. The difference was mainly due to glycine, which was found in significantly higher $(\mathrm{P}<0.001)$ amounts with NorP-cows on pasture feeding. The proportion of glycine in the total identified free amino acids was $9.7 \pm 9.0 \%$ with 0 -cows, $13.5 \pm 5.1 \%$ with ULP-cows, $7.7 \pm 3.4 \%$ with NorP-cows on indoor feeding and $56.4 \pm 21.0 \%$ with NorP-cows on pasture feeding. The corresponding figures for glutamic acid, which was quantitatively the most important amino acid with 0- and ULP-cows, were $36.5 \pm 29.6 \%, 19.8 \pm 19.2 \%, 5.7 \pm 4.0 \%$ and $3.9 \pm 2.1 \%$ of the total free amino acids. Besides the identified amino acids, there were a number of unidentified amino acid derivatives in the free amino acid fraction in all the feeding groups.

The total amount of amino acids freed by hydrolysis was the lowest with 0 -cows. The proportion of glycine of the amino acids of the hydrolysate was $48 \%$ with 0 -cows, $66 \%$ with ULP-cows and $84 \%$ with NorP-cows.
\end{abstract}

\section{Introduction}

Excretion of nitrogenous nutrients and their reabsorption takes place via the kidney. With amino acids, which are found in much larger amounts in the blood than in the urine, tubular reabsorption is effective. Of the $\alpha$-amino nitrogen filtered by the kidney glomeruli an estimated $98 \%$ is reabsorbed (PItTs 1944, Wright et al.1966). However, it has been shown that in ruminants $10-20 \%$ of the total urinary nitrogen is excreted as amino nitrogen, glycine being the main amino acid (DOAK 1952, BATHURST 1952).

In urea-fed dairy cows (VIRTANEN 1966, 1971) $5-6 \%$ of the total urinary nitrogen is excreted as free amino acids, and $8-10 \%$ as amino acids released by hydrolysis (ETTALA and Kreula, 1976). The purpose of the present study is to elucidate the excretion of single amino acids in free and bound form in the urine of test cows on urea-rich feed.

\section{Materials and methods}

Urine samples were taken from the test cows with urea as the sole ( 0 -cows) or partial (ULP-cows) source of nitrogen. The feeding of these cows has been 
reported in detail in an earlier publication (VIRTANEN 1966, VirTANEN et al. 1971). For comparison urine samples were also taken from cows on normal silage-cereal feed (NorP-indoor feed) and pasture feed (NorP-pasture feed).

The amino acids were isolated from the urine by Amberlite IR 120 cation exchange resin in $\mathrm{H}^{+}$-form. The free amino acids were isolated by the cation exchanger directly from the urine, and the amino acids of the hydrolysate after the urine had first been hydrolysed with $6 \mathrm{~N}$ hydrochloric acid in a nitrogen atmosphere at $106^{\circ} \mathrm{C}$ for $20 \mathrm{~h}$. The quantitative determination of the amino acids was performed with a Bio Cal BC 201 amino acid analyser.

\section{Results and discussion}

The total amount of identified free amino acids was $53.7 \pm 29.2 \mathrm{mg}$ with 0 -feed, $140.8 \pm 101.4 \mathrm{mg}$ with ULP-feed, $170.6 \pm 66.6 \mathrm{mg}$ with NorP-indoor feed and $763.4 \pm 1138.7 \mathrm{mg}$ with NorP-pasture feed per litre urine. At various sampling times the amounts of free amino acid varied greatly in all the feeding groups (Table 1). Of the single amino acids, glutamic acid had

Table 1. Free amino acids in the urine of dairy cows on 0-, ULP-, NorP-indoor and NorP-pasture feeds.

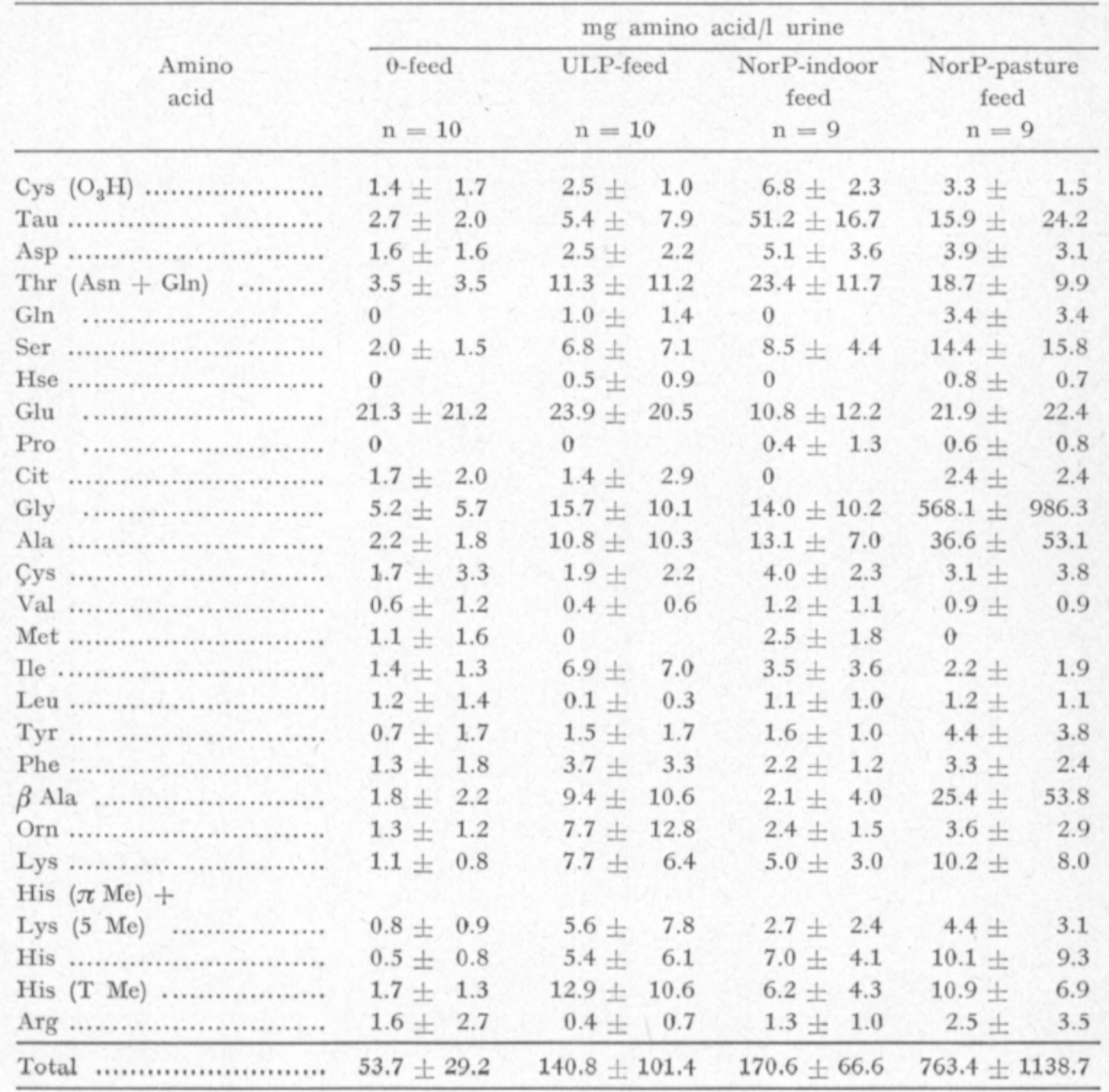


the highest excretion figure with 0 - and ULP-feed, followed by glycine, threonine, serine, taurine and alanine in this order. On NorP-indoor feed considerably larger amounts of taurine were excreted than the other amino acids. The amount of taurine excreted, as well as that of threonine, was also larger than with the other feeding groups. With NorP-pasture feed, in contrast, the main part of the free amino acids excreted was glycine $(56.4 \pm 21.0 \%)$, the figure as compared with the other feeding groups being statistically highly significant $(\mathrm{P}<0.001)$. Of all the total identified amino acids the proportion of essential amino acids was $16.9 \pm 12.6 \%$ with 0 -feed, $20.0 \pm 8.7 \%$ with ULP-feed, $24.3 \pm 3.8 \%$ with NorP-indoor feed and $12.2 \pm 7.1 \%$ with NorP-pasture feed (Table 2). The proportion of free glycine nitrogen in the total free amino acid nitrogen was $13.6 \pm 12.1 \%$ with 0 -cows, $16.7 \pm 7.0 \%$ with ULP-cows, $10.9 \pm 4.2 \%$ with cows on NorP-indoor feed and $60.0 \pm$ $19.8 \%$ with cows on NorP-pasture feed. In addition to the identified amino acids, a large number of unidentified amino acid derivatives were found in the free amino acid fraction which qualitatively were similar in all the feeding groups.

Table 2. Free amino acids in the urine of dairy cows on $0-$, ULP- and NorP-feeds, as a weight percent of the total amount of the identified amino acids.

\begin{tabular}{|c|c|c|c|c|}
\hline \multirow{3}{*}{$\begin{array}{c}\begin{array}{c}\text { Amino } \\
\text { acid }\end{array} \\
\text { Cys }\left(\mathrm{O}_{3} \mathrm{H}\right) \ldots \ldots \ldots \ldots \ldots \ldots \ldots \ldots \ldots \ldots \ldots\end{array}$} & \multicolumn{4}{|c|}{$w / w \%$ of total amount of identified amino acids } \\
\hline & $\begin{array}{l}0 \text {-feed } \\
\mathrm{n}=10\end{array}$ & $\begin{array}{l}\text { ULP-feed } \\
n=10\end{array}$ & $\begin{array}{c}\text { NorP-indoor } \\
\text { feed } \\
\mathrm{n}=9\end{array}$ & $\begin{array}{l}\text { NorP-pasture } \\
\begin{array}{l}\text { feed } \\
\mathrm{n}=9\end{array}\end{array}$ \\
\hline & $2.9 \pm 4.0$ & $4.1 \pm 5.4$ & $3.7 \pm 1.3$ & $1.0 \pm 1.6$ \\
\hline 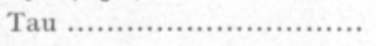 & $5.5 \pm 2.7$ & $5.3 \pm 5.5$ & $32.7 \pm 11.1$ & $8.8 \pm 9.9$ \\
\hline 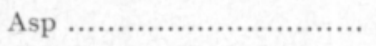 & $2.6 \pm 2.1$ & $2.9 \pm 2.7$ & $2.5 \pm 1.4$ & $0.9 \pm 0.7$ \\
\hline Thr $($ Asn + Gln $) \ldots \ldots \ldots \ldots$ & $5.4 \pm 7.4$ & $6.6 \pm 5.9$ & $12.9 \pm 3.7$ & $5.2 \pm 3.3$ \\
\hline Gln $\quad \ldots . .$. & 0 & $0.4 \pm 0.6$ & 0 & $0.8 \pm 1.1$ \\
\hline Ser $\ldots \ldots \ldots \ldots$ & $2.9 \pm 2.9$ & $4.0 \pm 2.3$ & $4.8 \pm 1.2$ & $2.5 \pm 1.3$ \\
\hline Hse ........ & 0 & $0.3 \pm 0.4$ & 0 & $0.1 \pm 0.1$ \\
\hline Glu $\quad \ldots .$. & $36.5 \pm 29.6$ & $19.8 \pm 19.2$ & $5.7 \pm 4.0$ & $3.9 \pm 2.1$ \\
\hline Pro $\ldots$ & 0 & 0 & $0.2 \pm 0.4$ & $0.1 \pm 0.1$ \\
\hline Cit $\ldots \ldots . .$. & $2.9 \pm 3.0$ & $1.4 \pm 2.9$ & 0 & $0.5 \pm 0.3$ \\
\hline 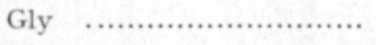 & $9.7 \pm 9.0$ & $13.5 \pm 5.1$ & $7.7 \pm 3.4$ & $56.4 \pm 21.0$ \\
\hline 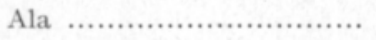 & $4.1 \pm 3.5$ & $7.5 \pm 3.8$ & $7.9 \pm 3.1$ & $5.8 \pm 3.8$ \\
\hline Cys $\ldots .$. & $2.2 \pm 3.5$ & $1.1 \pm 1.0$ & $2.9 \pm 0.8$ & $1.2 \pm 1.1$ \\
\hline 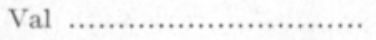 & $0.7 \pm 1.2$ & $0.2 \pm 0.3$ & $0.7 \pm 0.4$ & $0.3 \pm 0.3$ \\
\hline Met ........................... & $2.0 \pm 1.8$ & 0 & $1.8 \pm 0.2$ & 0 \\
\hline Ile $. . . \ldots \ldots \ldots \ldots . . . . .$. & $2.3 \pm 1.8$ & $3.8 \pm 3.2$ & $2.1 \pm 1.9$ & $0.8 \pm 0.8$ \\
\hline Leu ........ & $2.1 \pm 1.7$ & $0.1 \pm 0.2$ & $0.6 \pm 0.5$ & $0.4 \pm 0.4$ \\
\hline 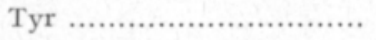 & $0.8 \pm 1.8$ & $3.3 \pm 5.2$ & $1.3 \pm 0.2$ & $1.3 \pm 1.1$ \\
\hline 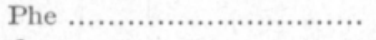 & $2.0 \pm 2.1$ & $1.6 \pm 1.2$ & $1.5 \pm 0.5$ & $0.9 \pm 0.6$ \\
\hline 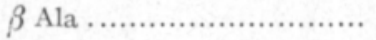 & $2.7 \pm 2.3$ & $4.6 \pm 5.1$ & $0.9 \pm 1.3$ & $2.5 \pm 1.7$ \\
\hline 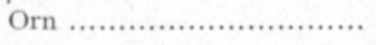 & $5.0 \pm 10.6$ & $3.7 \pm 4.5$ & $1.4 \pm 0.7$ & $0.6 \pm 0.4$ \\
\hline 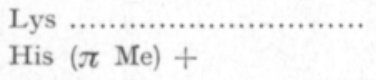 & $3.7 \pm 6.3$ & $4.4 \pm 2.2$ & $2.8 \pm 1.3$ & $2.4 \pm 2.1$ \\
\hline 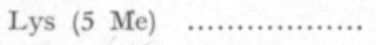 & $3.0 \pm 5.0$ & $3.3 \pm 2.8$ & $1.2 \pm 1.0$ & $1.5 \pm 1.2$ \\
\hline 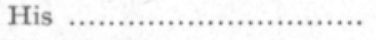 & $1.2 \pm 1.5$ & $2.9 \pm 2.4$ & $4.2 \pm 1.4$ & $2.6 \pm 2.2$ \\
\hline His $(\mathrm{T} \mathrm{Me}) \ldots \ldots \ldots \ldots \ldots \ldots$ & $3.4 \pm 3.2$ & $7.3 \pm 4.0$ & $3.8 \pm 2.5$ & $2.9 \pm 2.2$ \\
\hline 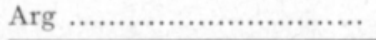 & $3.7 \pm 7.1$ & $2.0 \pm 4.4$ & $0.8 \pm 0.5$ & $0.9 \pm 1.2$ \\
\hline
\end{tabular}


Table 3. Amino acids in the hydrolysate of the urine of cows on 0-, ULP- and NorP-feeds, as a weight percent of the total amount of the identified amino acids

\begin{tabular}{|c|c|c|c|c|}
\hline \multirow[b]{2}{*}{$\begin{array}{l}\text { Amino } \\
\text { acid }\end{array}$} & \multicolumn{4}{|c|}{$\mathrm{w} / \mathrm{w} \%$ of total amount of identified amino acids } \\
\hline & $\begin{array}{l}0 \text {-feed } \\
n=7\end{array}$ & $\begin{array}{l}\text { ULP-feed } \\
n=7\end{array}$ & $\begin{array}{c}\text { NorP-indoor } \\
\begin{array}{c}\text { feed } \\
\mathrm{n}=4\end{array}\end{array}$ & $\begin{array}{c}\text { NorP-pasture } \\
\text { feed } \\
n=3\end{array}$ \\
\hline Tau .................. & $2.0 \pm 2.4$ & $1.0 \pm 0.9$ & 1.4 & 3.4 \\
\hline Asp ......... & $3.2 \pm 2.4$ & $2.1 \pm 0.7$ & 0.7 & 1.0 \\
\hline 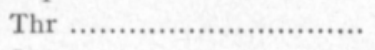 & $1.7 \pm 0.3$ & 0.9 & 0.4 & 0.5 \\
\hline 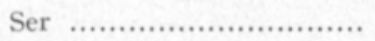 & $2.2 \pm 0.5$ & $1.0 \pm 0.2$ & 0.5 & 0.5 \\
\hline Hse ........................... & $2.3 \pm 1.8$ & $2.4 \pm 1.9$ & 0.6 & 0.2 \\
\hline ................... & $16.0 \pm 14.4$ & $8.6 \pm 2.8$ & 3.7 & 4.7 \\
\hline Pro $\quad$............................ & $3.4 \pm 1.9$ & $1.8 \pm 0.9$ & 1.2 & 0.4 \\
\hline 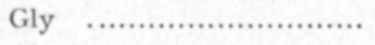 & $48.1 \pm 18.7$ & $65.9 \pm 1.6$ & 82.7 & 85.5 \\
\hline Ala ............................ & $4.4 \pm 1.1$ & $5.0 \pm 1.7$ & 0.8 & + \\
\hline 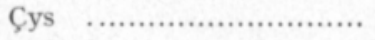 & $0.7 \pm 1.0$ & $0.6 \pm 0.3$ & 0.5 & 0.4 \\
\hline 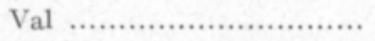 & $0.9 \pm 0.2$ & $1.0 \pm 0.4$ & 0.3 & 0.1 \\
\hline 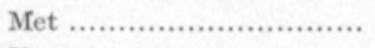 & $0.6 \pm 0.6$ & $0.3 \pm 0.5$ & 0.3 & 0.4 \\
\hline 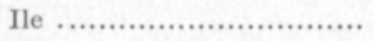 & $0.7 \pm 0.2$ & $0.7 \pm 0.3$ & 0.3 & + \\
\hline Leu .............................. & $1.1 \pm 0.2$ & $1.0 \pm 0.6$ & 0.5 & 0.4 \\
\hline Tyr .............................. & $0.4 \pm 0.3$ & $0.2 \pm 0.3$ & 0.8 & 0.1 \\
\hline 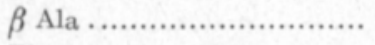 & $3.7 \pm 0.9$ & $1.8 \pm 0.4$ & 1.0 & 0.5 \\
\hline 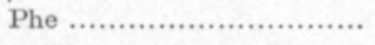 & $1.0 \pm 0.5$ & $0.6 \pm 1.0$ & C.7 & 0.4 \\
\hline 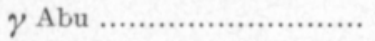 & $0.5 \pm 0.2$ & $0.4 \pm 0.1$ & 0.3 & 0.1 \\
\hline 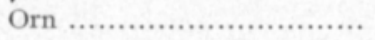 & $1.1 \pm 1.0$ & $0.8 \pm 0.7$ & 0.2 & 0.2 \\
\hline 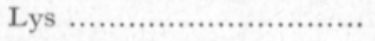 & $2.4 \pm 0.4$ & $2.2 \pm 1.0$ & 1.3 & C.4 \\
\hline 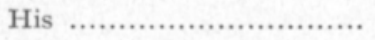 & $0.8 \pm 0.9$ & $0.5 \pm 0.9$ & 0.7 & 0.5 \\
\hline 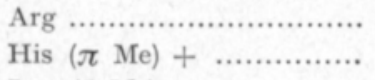 & $2.7 \pm 1.9$ & $1.4 \pm 0.8$ & 0.8 & 0.2 \\
\hline Lys (5 Me) & + & + & 0.3 & + \\
\hline His $(\mathrm{T} \mathrm{Me}) \ldots \ldots \ldots \ldots \ldots \ldots$ & + & + & + & 0.1 \\
\hline Amino acids, $g / 1$ urine ....... & $0.51 \pm 0.08$ & $1.25 \pm 0.84$ & 2.73 & 1.78 \\
\hline
\end{tabular}

The main amino acid of the hydrolysate of the urine in each feeding group was glycine, the proportion of which was $48.1 \%$ of the total amino acids of the hydrolysate with 0 -cows, $65.9 \%$ with ULP-cows $82.7 \%$ with cows on NorP-indoor feed and $\mathbf{8 5 . 5} \%$ with cows on NorP-pasture feed. The total amount of the amino acids of the hydrolysate was lower with 0 -cows than with the cows of the other feeding groups (Table 3).

Amino acid determinations on the urine of the test cows were performed during several years, with the result that the separation efficiency of the chromatography columns of the amino acid analyser varied to some extent. Glutamine and asparagine for example sometimes overlapped threonine, but the whole peak was calculated as threonine in the results. Another source of error was that the urine samples had to be concentrated, since their amino acid contents varied widely. Although amino acid runs were performed on each sample at different concentrations, it is possible that amino acids occurring only in small amounts remained undetermined.

When comparing the results with the earlier ones, it can be observed that those obtained on the amino acids of the urine of cows on pasture feed cor- 
respond to the results obtained by BATHURst (1952). According to his studies, $90 \%$ of the amino nitrogen of the hydrolysed urine of cows on pasture feed is glycine nitrogen; the proportion of free glycine of the total amount of glycine is $18 \%$ and that of free glycine nitrogen of the free amino nitrogen $70 \%$. Also, according to Coulson (1959), mainly glycine is excreted in free form in the urine of cows on pasture feed, and also glutamic acid, threonine, alanine, leucine and phenylalanine to some extent. No data about the amino acid composition of the urine of cows on indoor feed could be found in the literature.

In all the feeding groups' there were large amounts of glycine in the hydrolysate of the urine, but there were differences between the groups. According to BAthurst (1952), $55 \%$ of the glycine in urine hydrolysis was derived from hippuric acid. With our test cows, particularly with the 0 -cows, considerably smaller amounts of hippuric acid were found in the urine than with NorP-cows (unpublished data).

The interrelation between the composition of the feed and the free amino acids of the urine has been studied extensively, particularly with humans and rats. With rats an inverse correlation between the growth effect of protein and the amount of amino acids in the urine has been observed (PEARCE et al. 1947). If the amino acid composition of the feed is unbalanced the amount of amino acids in the urine increases (SAUBERLich and SAlmon 1955). KucuKALIC (1974) found that when rams and rats received restricted amounts of protein in their feed the urinary glycine content was $50-80 \%$ of the free amino acids. The situation is probably different with dairy cows, since in the present study pasture cows receiving sufficient amounts of protein had glycine figures of $56.4 \pm 21.0 \%$.

The results show that the free amino acids in the urine of 0 - and ULPcows did not differ essentially from those in the urine of cows on NorPindoor feeding; further, there were clear differences between NorP-indoor cows and NorP-pasture cows in both the total amounts of free amino acids and also in the glycine contents of the urine, even though the two groups were fed according to the norms. Thus it is not possible on the basis of the present study to draw any conclusions about the effect of the feed protein on the free amino acids of the urine of the dairy cow.

The elucidation of all the ninhydrin-positive compounds would require further investigation.

\section{REFERENCES}

Bathurst, N. O. 1952. The amino acids of sheep and cow urine. J. Agric. Sci. 42: 476-478. Coulson, C. B., Davies, P. J. \& Evans, W. C. 1959. Clinical biochemistry of farm animals. 1. Proteins and amino acids of the body fluids of cattle and sheep. J. Comp. Path. 69: 367-376. (Ref. Nutr. Abstr. Rev. 30: 2141.)

DоAк, B. W. 1952. Some chemical changes in the nitrogenous constituents of urine when voided on pasture. J. Agric. Sci. 42: 162-171.

EttalA, T. \& Kreula, M. 1976. Urinary nitrogen compounds in dairy cows fed urea as the sole or partial source of nitrogen. J. Scient. Agric. Soc. Finl. 48: 323-335. 
Kucukalic, E. 1974. Comparative study of free amino acids of the blood serum and urine in the ram and rat depending on the regimen of feeding. Veterinaria (Sarajevo) 23: 241260. (Ref. Chem. Abstr. 82: 138134.)

Pearce, E. L., Sauberlich, H. E. \& Baumann, C. A. 1947. Amino acids excreted by mice fed incomplete proteins. J. Biol. Chem. 168: 271-282.

PitTs, R. F. 1944. A comparison of the renal reabsorptive processes for several amino acids. Amer. J. Physiol. 140: 535-547.

SAUBERLich, H. E. \& SALMON, W. D. 1955. Amino acid imbalance as related to tryptophan requirement of the rat. J. Biol. Chem. 214: 463-473.

Virtanen, A. I. 1966. Milk production of cows on protein-free feed. Science 153: 1603-1614.

- - 1971. Protein requirements of dairy cattle - artificial nitrogen sources and milk production. Milchwiss. 26: 129-138.

Wright, L. A. \& Nicholson, T. F. 1966. The plasma levels, filtered loads, excretion rates, and clearances of a number of ninhydrin-positive substances by normal fasting dogs. Can. J. Physiol. Pharmacol. 44: 195-201. (Ref. Nutr. Abtsr. Rev. 36: 6272.)

Ms received September 28, 1977

\title{
SELOSTUS
}

\section{Lypsylehmien virtsan aminohapoista urean ollessa ruokinnan ainoana tai osittaisena typenlähteenä}

\author{
Matti Kreula ja Terttu Etrala \\ Biokemiallinen Tutkimuslaitos, Kalevankatu 56 b, 00180 Helsinki 18
}

Virtsassa vapaina ja sitoutuneina erittyvät aminohapot on määritetty kvantitatiivisesti lypsylehmiltä, joilla urea- ja ammoniumtyppi on ollut ainoana (0-lehmät) tai osittaisena (ULPlehmät) typenlähteenä. Vertailun vuoksi on aminohappomäärityksiä tehty myös tavanomaisella säilörehu-viljaruokinnalla ja laidunruokinnalla olleiden lehmien virtsoista (NorP-lehmät).

Vapaiden aminohappojen kokonaismäärä ( $\mathrm{mg} / \mathrm{l}$ virtsaa) on ollut pienin 0 -lehmillä ja suurin NorP-lehmillä laidunruokinnalla. Ero on johtunut pääasiallisesti glysiinistä, jota NorP-laidunruokinnalla on ollut erittäin merkitsevästi $(\mathrm{P}<0.001)$ enemmän kuin muilla ruokintaryhmillä Glysiinin osuus kaikista tunnistetuista aminohapoista on ollut 0 -lehmillä $9.7 \pm 9.0 \%$, ULPlehmillä $13.5 \pm 5.1 \%$, NorP-sisäruokinnalla $7.7 \pm 3.4 \%$ ja NorP-laidunruokinnalla $56.4 \pm$ $21.0 \%$. Glutamiinihappoa, joka on ollut määrällisesti tärkein aminohappo 0- ja ULP-lehmillä, on ollut vastaavasti $36.5 \pm 29.6 \%, 19.8 \pm 19.2 \%, 5.7 \pm 4.0 \%$ ja $3.9 \pm 2.1 \%$ kaikista aminohapoista. Tunnettujen aminohappojen lisäksi on vapaiden aminohappojen fraktiossa ollut kaikilla ruokintaryhmillä joukko tunnistamattomia aminohappojohdannaisia.

Hydrolyysissä vapautuvien aminohappojen kokonaismäärä on ollut alhaisin 0-lehmillä. Glysiinin osuus hydrolysaatin aminohapoista on 0 -lehmillä ollut $48 \%$, ULP-lehmillä $66 \%$ ja NorP-lehmillä $84 \%$. 